DEMOGRAPHIC RESEARCH

VOLUME 32, ARTICLE 13, PAGES 397-420 PUBLISHED 11 FEBRUARY 2015

http://www.demographic-research.org/Volumes/Vol32/13/

DOI: $\quad$ 10.4054/DemRes.2015.32.13

Research Article

\title{
Religion and fertility: The French connection
}

\section{Thomas Baudin}

(C) 2015 Thomas Baudin.

This open-access work is published under the terms of the Creative Commons Attribution NonCommercial License 2.0 Germany, which permits use, reproduction \& distribution in any medium for non-commercial purposes, provided the original author(s) and source are given credit. See http://creativecommons.org/licenses/by-nc/2.0/de/ 


\section{Table of Contents}

$\begin{array}{lll}1 & \text { Introduction } & 398\end{array}$

2 Detection of the theoretical mechanisms at play 402

$\begin{array}{lll}3 & \text { Estimation strategy } & 405\end{array}$

$4 \quad$ Results $\quad 407$

4.1 Impact of religion and of economic characteristics 407

4.2 The particularized ideology and socialization hypotheses 410

$5 \quad$ Robustness checks $\quad 412$

5.1 An alternative measure of religiousness 412

$\begin{array}{lll}5.2 & \text { Alternative samples } & 413\end{array}$

$\begin{array}{lll}5.2 .1 & \text { Completed fertility } & 413\end{array}$

$\begin{array}{lll}\text { 5.2.2 } & \text { Entire sample } & 413\end{array}$

$6 \quad$ Conclusion $\quad 414$

$\begin{array}{lll}7 & \text { Acknowledgments } & 414\end{array}$

$\begin{array}{ll}\text { References } & 415\end{array}$

$\begin{array}{ll}\text { Appendix } & 419\end{array}$ 


\title{
Religion and fertility: The French connection
}

\author{
Thomas Baudin ${ }^{1}$
}

\begin{abstract}
BACKGROUND

France has been among the first countries to become secularized but has preserved a Catholic identity. Before 2008, French laws made it very difficult to collect data on an individual's religious affiliation. The dataset "Enquête Mode de Vie des Français" is the first allowing one to collect such data.
\end{abstract}

\section{OBJECTIVE}

I investigate the impact that being a Catholic has on fertility in France. I answer two main questions: (i) Do Catholic people have more children than others? (ii) Why is this the case?

\section{METHODS}

Fertility is measured by the number of children ever born. I use the dataset "Enquête Mode de Vie des Français" and Zero-Inflated Poisson regression models. Individual religiosity is approximated by the attendance at religious services.

\section{RESULTS}

I first show that practicing Catholics have more children than the rest of the population, while this is not verified for nominal Catholics. I also construct two variables allowing me to detect that particularized ideology mechanisms (Goldscheider 1971) can explain in part why religion has an impact on fertility in my dataset. Nevertheless, I cannot exclude the social interaction hypothesis. The multivariate analysis I provide also validates the main mechanisms of the rational actor model.

\section{CONCLUSIONS}

I implement several robustness checks showing that my main results are robust to changing my regression model (ordered probit and linear regressions) and the way religiousness and fertility are measured.

\footnotetext{
${ }^{1}$ Centre de Recherche en Démographie et Sociétés - Université Catholique de Louvain and EQUIPPE - Université de Lille Nord de France. E-Mail: thomas.baudin@uclouvain.be. Send mail to: Centre de Recherche en Démographie et Sociétés, Bureau A-146, Université Catholique de Louvain 1, Place Montesquieu, boîte L2.08.03 B-1348 Louvain-la-neuve Belgium.
} 


\section{Introduction}

Demographers have initiated a long tradition that consists in studying the relationship between religion and fertility. To do so, they have constructed a framework in which alternative theories compete and complete each other. The present paper is a contribution to this literature, and focuses on contemporary France. More precisely, it studies the impact that being a Catholic has on fertility, measured either by the number of children ever born, or by completed fertility.

Due to its limitation to France, this study is characterized by several specificities. First, despite its Catholic identity, France is very secularized (Hervieu-Leger 2004) and it was the first European country to become secular. Lesthaeghe and Wilson (1986) argue that early secularization in France has been one major reason why the French fertility transition has been concomitant with the mortality transition. ${ }^{2}$ This explains why the population did not explode during the demographic transition. Since 1945, the proportion of churchgoing Catholics has kept decreasing dramatically. This process accelerated during the seventies. Hervieu-Leger (2004) estimates that in 2001, the proportion of French people who engage in at least one element of Catholic practice ${ }^{3}$ per month was about $12 \%$. Interestingly enough, despite this early and strong secularization, fertility in France is among the highest in Europe. ${ }^{4}$ As shown in Figure 1, the total fertility rate in France decreased from the beginning of the 20th century to the nineties; then it increased and has almost reached the replacement level. ${ }^{5}$

\footnotetext{
${ }^{2}$ Analyzing the decline of fertility in Europe and developing countries, Watkins (1987) more generally states that "There is no reason to believe that institutional and ideational change cannot be as powerful solvents of traditional practices as economic change, or as rapid."

${ }^{3}$ Either going to church, going to catechism, confession, etc. Frejka and Westoff (2008) provide an enlightening discussion about secularization in Europe.

${ }^{4}$ In 2009 , the European average total fertility rate was 1.59 , while the French total fertility rate was equal to 2 (data from Eurostat).

5 In 1994, the French government started implementing generous family policies. Subsidies for births in particular, increased for families deciding to have a third child. Furthermore, strong efforts have been made to provide day care and to reduce the cost of child care by sitters. Toulemon, Pailhé, and Rossier (2008) argue that these family policies have created highly positive attitudes towards two- or three-child families. Such policies have largely enjoyed a consensus among politicians and French residents. Laroque and Salanié (2005) also find that financial incentives have been efficient in increasing fertility in France.
} 
Figure 1: $\quad$ French total fertility rate during the 20th century. Data from Institut National de la Statistique et des Etudes Economiques

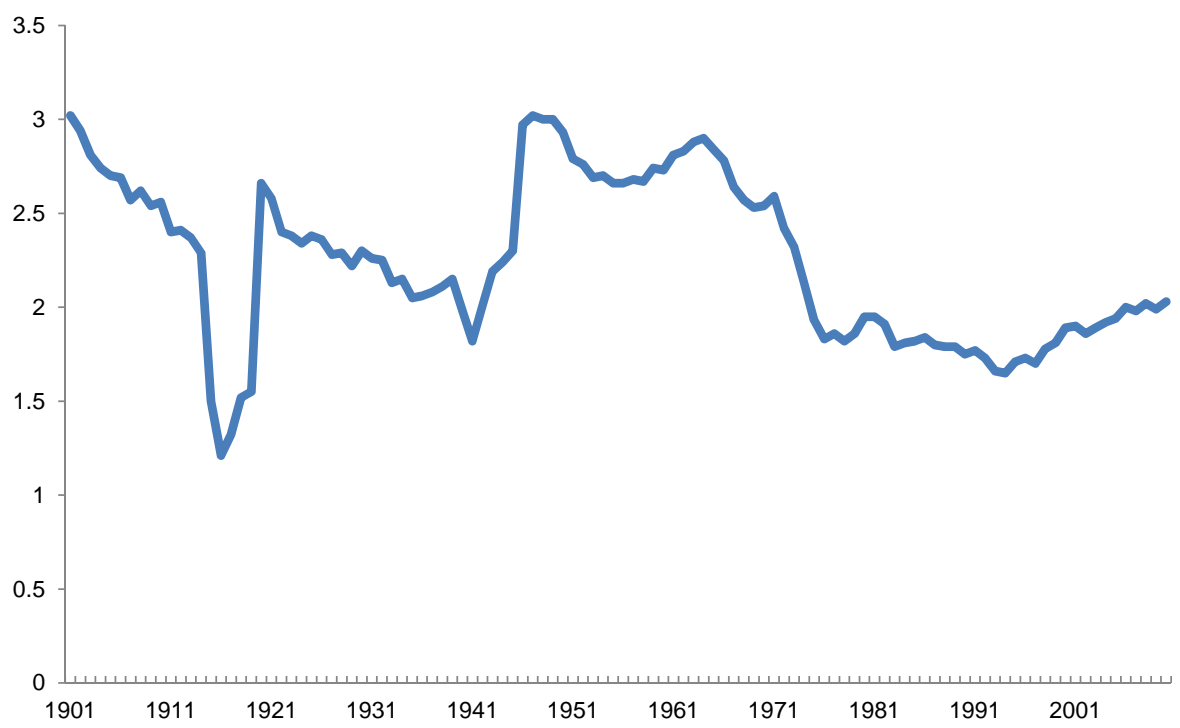

Second, until 2008, French laws made it very difficult to collect data on an individual's religious affiliation. As a consequence, results about the relationship between religion and fertility are lacking for France. If religion had no impact on fertility, this specificity would not weaken the analysis of individual fertility behavior, but in line with the literature, this paper shows that this is not actually the case.

The data set "Enquête Mode de Vie des Français" contains data about religion and several dimensions of the respondents' religiousness, as well as complete information about their economic situation (income, savings, wealth, history on the labor market, etc.), their lifestyle (health, addictions, consumer habits, etc.), their risk aversion and their values (religion, politics, attitude toward foreigners, etc.). This allows me to test a large set of theories and to implement several robustness tests.

In the present study, I quantify the impact of religion and religiousness on the number of children ever born (CEB). Due to the limited size of the data set, the number of individuals who have a religion which is not Christian is very low. ${ }^{6}$ For this reason, I only compare the fertility of Catholics to the fertility of people who declared they had no religious affiliation (in the sense that they were not raised in a religious family). I investigate

\footnotetext{
${ }^{6}$ Among the women without missing information in the data set, there are $82.1 \%$ of Catholics, $2 \%$ of Protestants, $0.16 \%$ of Orthodox Christians, $0.66 \%$ of Jews, $0.44 \%$ of Muslims and $14 \%$ of non-religious people.
} 
several dimensions of "being a Catholic". I explore the impact of having been raised in a Catholic family, of believing (being a Catholic believer or not) and of religiousness on fertility. Religiousness will be measured either by attendance at religious services or by a self-assessment of the importance of religion in one's daily life.

In addition to the religious variables, I construct two additional cultural variables. The first one is denominated "Family Values". F Family values are measured by the replies to the following questions: "Which of the following values do you (or would you) try to transmit to your children?" and "Among the same set of values, which ones did your parents transmit to you?" Respondents were allowed to choose three answers out of twelve such as "Independence", "Taste for Work", "Generosity", "Happiness", "Honesty", "Family Values", etc. A respondent who chooses "Family Values" for one of the questions is assigned the value one, two if she chooses it for both questions, and zero otherwise. ${ }^{8}$ The second variable I introduce measures the respondent's number of brothers and sisters. This a proxy for fertility norms which have been instilled in the respondent by her parents.

The summary statistics in Table 1 indicate that in my sub-sample, women who have been raised in a Catholic family have more children than non-Catholics, and this fertility differential is even stronger between Catholic churchgoers ${ }^{9}$ and non-Catholics. In this paper, I first try to determine if this fertility differential is due to the fact that Catholicism implies higher fertility, or that Catholics are characterized by living conditions that lead them to have more children than others. In other words, is there any causality between Catholicism and a high fertility rate? Interestingly enough, Catholics have a lower education level than non-Catholics and, once again, this differential is stronger between nonCatholics and churchgoing Catholics. Furthermore, a much lower proportion of Catholics never get married, which can also imply a higher fertility rate than non-Catholics. Finally, Catholics - and especially churchgoers - are much older than non-Catholics, which could explain their lower education level, their higher marriage rate, as well as their higher fertility (they have more often completed their reproductive process).

\footnotetext{
${ }^{7}$ It corresponds to the French "Le sens de la Famille".

${ }^{8}$ Alesina and Giuliano (2007) find that strong family ties are associated with higher fertility with a different method. They measure family ties with individual responses from the World Value Survey "regarding the role of the family and the love and respect that children need to have for their parents" for over 70 countries. They show that strong family ties imply a relatively stronger reliance on home production than on labor market participation. It results in women having a lower labor force participation and a higher fertility.

${ }^{9}$ In the summary statistics, a person is considered as a churchgoer if she goes to mass frequently in the year in addition to religious holidays and religious celebrations like weddings and baptisms. A richer definition will be used in the regressions.
} 
Table 1: $\quad$ Summary statistics for the sub-sample used in the regressions

\begin{tabular}{lcccc}
\hline Variables & Sample & All Catholics & Church-goers & Non-Catholics \\
\hline Proportion in \% & 100 & 82.5 & 30.04 & 17.5 \\
Mean number of CEB & 1.58 & 1.62 & 1.84 & 1.36 \\
\% with primary education & 8 & 8.9 & 11.8 & 3.6 \\
\% Higher Education & 37.8 & 37 & 34.8 & 42.5 \\
\% never married & 18.1 & 17 & 13.3 & 24.7 \\
\% over 45 yo & 52.3 & 56 & 67 & 31.6 \\
\% under 28 yo & 10.46 & 9.14 & 6.2 & 18.6 \\
\hline
\end{tabular}

The main advantage of using multivariate econometrical methods is that it allows me to measure the impact of being a Catholic, controlling for all the differences I have mentioned above. Doing so, I find that having been raised in a Catholic family has no effect on fertility, while defining oneself as a religious believer has a positive and significant impact on individual fertility a priori. Nevertheless, the latter effect loses its significance when the degree of religiousness is introduced. In the end, religiosity is the only religious variable that really matters for fertility. This result is validated whether religiosity is measured by church attendance or by the respondent's subjective assessment of the importance of religion in her daily life.

This result is in line, for instance, with Heineck (2006) who studies the link between religion and fertility in Austria. He finds that women who are "strong Catholic believers" are expected to have larger families than women without any religious belief. Hacker (1999) shows that the degree of Christian conservatism is a good proxy for religious sentiment for white American-born women in the nineteenth century. Conservatism is measured by a dummy variable indicating whether individuals belong to a specific religious group, such as Congregationalists, Universalists, Lutherans or Catholics. He finds that this proxy has a significant effect on women's fertility: more conservatism implies a higher total fertility rate. Williams and Zimmer (1990), Adserá (2006), as well as Amin, Diamond, and Steele (1997) show that religiousness, measured by church attendance has a positive and significant impact on fertility. ${ }^{10}$

One major limitation of my data set is that I measure the relationship between current religiosity and fertility, instead of the relationship between religiosity before births and fertility. Indeed, studies like Stolzenberg, Blair-Loy, and Waite (1995) and McCullough et al. (2005) show that having a child has a significant impact on parents' religiosity in the US. As a consequence, measuring the impact of current religiosity on fertility entails a problem of causality: I do not know if the correlations quantify the impact of

${ }^{10}$ Note that Brañas-Garza and Neuman (2007) find that, among Spanish Catholics, the exposure to religious practice during childhood has a positive impact on fertility. They also find that the respondent's current religiosity has no effect on her fertility. However, the exposure to religious practice during childhood and current religiosity are strongly correlated. 
past religiosity on fertility, or the impact of motherhood on current faith. Nevertheless, Berghammer (2012) shows that there is no reverse causality for a European country like the Netherlands. One main reason for this result is that, unlike what is found in the US, in the Netherlands, parishes do not have a strong welfare function. Thus, after a birth, a woman has no financial incentive (benefit) to increase her proximity and interaction with the Catholic church. From this point of view, France is very similar to the Netherlands. In France, laws enforce a strict segregation between religion and public institutions, and the welfare state is very prominent (see for instance Mayeur 2005). This does not mean that religious organizations are not a source of welfare and socialization, but they are very minor compared to public and non-religious institutions. So although my data set cannot statistically exclude reverse causality, its importance is probably weak.

The rest of the paper is organized as follows. In Section 2, I discuss the theoretical contribution of the present study. Then, in Section 3, I expose my estimation strategy and in Section 4, I discuss my results. Section 5 displays some robustness checks and Section 6 concludes.

\section{Detection of the theoretical mechanisms at play}

Building on Goldscheider (1971), a vast literature has tried to explain fertility differences between religions and religious groups. ${ }^{11}$ This literature identifies four main hypotheses to explain the impact of religion on fertility: (i) the characteristic hypothesis, (ii) the particularized ideology hypothesis, (iii) the minority status hypothesis, and (iv) the socialization hypothesis.

The four main hypotheses presented here aim at explaining the fertility differences between alternative religious groups. In the present paper, I focus on the fertility differences between Catholics and others. As explained in the introduction, I first find that only churchgoing Catholics have significantly more children than others. It implies that the "others" are non-religious people and non-churchgoing Catholics. In this sense, the data set I use is fit to test the alternative hypotheses mentioned above. The contribution of this paper to the theory consists in a quantitative test detecting some mechanisms at play in the data set which are compatible with the alternative hypotheses. Interestingly enough, Mosher, Johnson, and Williams (1992) show that none of these hypotheses fully explain the fertility differential between Catholics and Protestants in the United States. I reach a somewhat identical conclusion for France using quantitative methods and concerning the fertility differences between churchgoing Catholics and others.

The characteristic hypothesis mainly conjectures that once all the individual characteristics have been taken into account, religion should not have any impact on fertility.

\footnotetext{
${ }^{11}$ See among others, Zhang (2008), as well as Mosher, Johnson, and Williams (1992) for the United States and Agadjanian (2001) for Mozambique.
} 
Although Brañas-Garza and Neuman (2007) find no time-persistent differences in fertility rate between the main monotheistic religions, this theory is not verified in many studies that take religiosity into account (as mentioned above, see Adserá (2006) and others). In this paper (Table 2), I also show that although a large set of individual characteristics are accounted for, churchgoing Catholics have more children than others (non-churchgoing Catholics and non-religious). In my main estimation, I evaluate that, ceteris paribus, a woman who is a very regular churchgoer (goes to mass at least once a week) has $24 \%$ more children than a woman who never goes to church. The minority status hypothesis can also be easily rejected to explain why churchgoing Catholics have more children than others in France. Indeed, Catholics are far from conforming in France, and high fertility norms have been demonstrated among churchgoing Catholics (see for instance Lesthaeghe 1977).

The particularized ideology hypothesis states that religions are characterized by specific views about fertility, thus inducing fertility differences between these groups, as well as between specific religious groups and non-religious people. Among others, Lesthaeghe and Wilson (1986) show that, during the Industrial Revolution, European Catholics were characterized by the adherence to high fertility norms and family-oriented values. The persistence of this ideology in France is underlined, for instance, by Prioux and RégnierLoilier (2008). The socialization hypothesis argues that religious institutions play a major role in determining individual fertility. Indeed, because of the interactions taking place through these religious institutions, each member's decisions or lifestyle shapes the other members' behavior. ${ }^{12}$ Disentangling these two effects is difficult as the conclusions drawn from these two theories are not incompatible. Nevertheless, the Family Values and Parental Fertility variables indicate that the particularized ideology plays a role, but that the socialization hypothesis cannot be excluded. This result appears in Models A, B and $\mathrm{C}$ in Table 3.

I find that both the Family Values and Parental Fertility score variables have a positive and significant impact on the respondent's fertility: having been raised in a large family in which family values were important significantly increases the respondent's fertility. Including these two variables in the regression does not imply that being a churchgoing Catholic no longer has an impact on fertility, however its effect is smaller and even less significant. How can this result be interpreted?

I argue that the positive impact of both the adherence to family values and having been raised in a large family makes the particularized ideology hypothesis the likelier explanation. Indeed, among others, Lesthaeghe (1977) shows that, in Western Europe during the Industrial Revolution and subsequently, the Catholic Church promoted family values, among which having a large family was very important. Furthermore, having been raised in a large family instils high fertility norms to children, at least in part. When these two

\footnotetext{
12 In economics, papers by Bisin and Verdier (2001) developed a theoretical model of cultural transmission that is, at least in part, compatible with this framework.
} 
variables are included in the regressions, a part of the reason why being a churchgoer increases fertility is explained, and the impact of being a churchgoer is smaller. Nevertheless, even when these two variables are included, being a churchgoing Catholic still has a positive and significant impact on fertility. Why is this the case? Two phenomena are at play. First, the two variables that I have constructed allow me to detect that the particularized ideology has an impact, but they are imperfect and do not allow one to control for it fully. Furthermore, we can suspect that the alternative mechanism is also at play, so that the socialization process has an impact on fertility in my sample. ${ }^{13}$

Interestingly enough, the results I find are also in line with the rational actor model described by Pollak and Watkins and developed jointly by economists and demographers. This model argues that given agents' preferences, their behavior can be explained by their individual characteristics which shape the costs and benefits of having children and how many. The economic analysis of fertility behaviors enriched with microeconomic foundations since the seminal approach of Becker and his co-authors (1960, 1973, and 1976). The Beckerian theory assumes that children are time-consuming, especially for women. This implies that a higher female income results in a lower fertility rate. ${ }^{14}$ The household theory of fertility shows that an increase in women's income reduces their fertility, while an increase in men's income increases the household's fertility. ${ }^{15}$ These standard mechanisms of endogenous fertility models have largely been evidenced by empirical studies without including cultural variables. ${ }^{16}$

Pollak and Watkins show very clearly that this model is compatible with the notions of culture and diffusion, at least in part. ${ }^{17}$ The present paper can also be considered as part of a large economic literature that tries to validate the rational actor model in which culture is a dynamic determinant of rational behaviors (see Guiso, Sapienza, and Zingales 2006,

\footnotetext{
${ }^{13}$ Notice that an alternative interpretation could present the positive impact of parental fertility as increasing the likelihood of the social interaction hypothesis. Indeed, following the framework of Bisin and Verdier (2001), family is the first social institution transmitting norms and values that a child is exposed to. In other words, Catholic parents are also members of the Catholic institution whom children are in contact with. Thus an imitation process can arise. Parental fertility may also measure alternative transmissions from parents to children, such as social position and location. Nevertheless, this variable allows me to control the results for these effects. ${ }^{14}$ Becker and Tomes (1976) argue that an increase in the parental income incites parents to have fewer children who will be better educated because the income elasticity of demand for quality is higher than the income elasticity of demand for quantity.

${ }^{15}$ See, for instance, Browning, Chiappori, and Lechene (2006) for a review of this literature.

${ }^{16}$ See Hotz, Klerman, and Willis (1993) for a review of this literature. The absence of cultural determinants was essentially due to two phenomena: (i) the lack of data sets, which prevent one from clearly identifying and measuring cultural variables, and (ii) Becker \& Stigler's critique stating that: "explaining the evolution of behaviors by changes in tastes provides endless degrees of freedom" (1977, p. 89).

${ }^{17}$ A version of this model has been nicely developed in a formal and general way by Bisin and Verdier (2001) and applied to the fertility transition in Western Europe by Baudin (2010). These contributions can be understood as attempts to formalize Easterlin's synthesis model of fertility (see Easterlin, Pollak, and Wachter 1980) which is also compatible with the rational actor model where culture is endogenous.
} 
for a review of the literature). In this literature, religion is often chosen to approximate culture, but as any approximation, it is incomplete and disputable. ${ }^{18}$

\section{Estimation strategy}

The data set consists of 3,826 French individuals aged between 18 and 93 . The population is divided between 2,080 women and 1,746 men. In the main regressions, only women are considered. After having deleted the missing observations, the sub-sample comes down to 1,793 observations.

In the main regressions, I study the impact of religion on the number of children ever born (CEB) and not on women's completed fertility. This allows the sample size to be larger and to extend the study to a greater number of generations. If religion does not have the same impact on all generations of women, restricting the analysis to older women could lead to biased estimations. However, during robustness checks, the subsample of women who have completed their fertility is studied. The results will be close to those I get with CEB.

As not all women in the sample have completed their fertility, their age has a strong influence on their fertility. The older a woman is, the higher her fertility. This partly comes from the postponement of the first birth. Furthermore, women over 45 are expected to have completed their reproduction process.

Directly introducing the respondent's age somewhat increases the overall fit of the model. However, the effect of age reflects much more complex phenomena than the simple position of the respondent in her "reproductive process". Indeed, age also reflects important cohort effects. During the second half of the twentieth century, France experienced, among other major transformations, a generalization of education, at least one profound modification in family policies (1994), a strong decrease in the influence of Catholicism, a liberalization of the marriage market, and a diversification of the forms of unions. The standard deviation of age is about 16 years. A 16-year age difference between two women can explain their differences in fertility because they are not in the same position in their reproductive process, but also because they have experienced differences in the quality of the education system, in family policies, or in the prevalence of religious norms in the whole society among others.

Only the position in the reproductive process is used in the regressions: I control my results by introducing an "under 28 years old" and "over 45 years old" variable. ${ }^{19}$ This is

\footnotetext{
${ }^{18}$ A noticeable exception lies in Fernández and Fogli (2007) who show, without using religious variables, that culture is important to the understanding of female work and fertility decisions.

${ }^{19}$ By assumption, a woman can be in one of the following situations: not fertile (under 16 years old, not useful here), fertile but younger than the average age at first birth (28 for France in 2006), fertile and older than the average age at first birth, and in the "completed fertility position" (over 45 by assumption).
} 
called the dummy strategy. It makes the interpretation of the effect of age easier. Notice that these dummies also capture cohort effects, but the latter will be easier to identify. ${ }^{20}$

When measuring the impact of religion, it is important to discriminate between the adherence to a specific religion and religiousness. Here, religious affiliation refers to the answer to the question: "In which religion have you been raised?". As mentioned in the introduction, I restrict my study to Catholics and people who have not been educated in a religious family. ${ }^{21}$ Faith is measured by the answer to the question: "Are you a believer?".

As in Williams and Zimmer (1990), Adserá (2006) and Amin, Diamond, and Steele (1997), the degree of religiousness is first measured by attendance at religious services. The "Attendance at Religious Services" variable goes from one to six. It is equal to one if the respondent says that she never attends religious services, and six if she attends services at least once a week. It increases with the attendance at services. For robustness checks, another measure of religiousness is provided: people were asked to evaluate the importance of religion in their own life from zero to ten. This measure is discussed in Section 5 .

The women in the sub-sample are not necessarily married because, once again, reducing the analysis to married women would induce a selection bias. ${ }^{22}$ It can reasonably be expected that married women are not characterized by the same sensitivity toward religion and family values as non-married women. I obviously control my results for the respondent's situation on the marriage market.

The rational actor model argues that a woman's education and income play a major role in the determination of optimal fertility. Two dummies are provided to control whether the respondent only has a primary education level or a university education level. Two variables are needed to measure income: female income and male income. The data set contains information about the respondents' net annual income and their household's total income. Thus, the man's income can easily be inferred. ${ }^{23}$ Notice that an endogeneity bias can be suspected. Indeed, fertility and income may have common determinants which are not taken into account in the present paper. For example, one can expect that subsidies for day care increase both fertility and income (higher labor force participation). This problem has been investigated to validate the robustness of my results (see Baudin 2012).

Fertility at the micro level consists in a count variable. Long and Fresse (2006) un-

${ }^{20}$ In Baudin (2012), results are also provided when the age is directly introduced into the regressions. The impact of religiosity, parental fertility and transmission of family values is still positive and significant.

${ }^{21}$ The "Religious Family of Origin" variable takes the value 1 if the respondent has been raised in a religious family.

22 This choice is also made, for instance, by Miranda (2008) and Mosher, Johnson, and Williams (1992).

${ }^{23}$ Notice that, as in Fernández and Fogli (2007), Melkersson and Rooth (2000), and Miranda (2008) among others, the reported income is the current income, whereas endogenous fertility models deal with the life cycle income. As in these contributions, my results are controlled by the respondent's education and age in order to limit this weakness. 
derline that count data have to be analyzed with Poisson regressions or negative binomial regressions in order to avoid any doubt regarding inconsistency and inefficiency. Individual data on fertility structurally exhibit a zero-inflated distribution. This characteristic comes both from the postponement of the first birth in developed countries, and the increase in childlessness since the Second World War (see Rowland 2007). In France, the average age at first birth was very close to 28 in 2006. My regressions make it clear that the ZIP regression model should be preferred to a simple Poisson regression model and to a zero-inflated negative binomial regression model. ${ }^{24}$

I implement several robustness checks. Their goal is to verify that the impact of religion and proxies for cultural transmission on fertility are not spurious. To do so, an alternative measure of religiousness is provided. Furthermore, two alternative samples are studied. The first sample only includes women over 45 in order to measure the impact of religion on completed fertility. The second sample includes men. It allows one to supress any doubts about the effect of sample selection on the relationship between religion and fertility. ${ }^{25}$ All robustness checks indicate that religion and the transmission of values inside the family are relevant to explain fertility in France, and that the ZIP regression is the best model to describe fertility choices in the present framework.

\section{Results}

In a first subsection, I show that religiosity is an important determinant of fertility in a context where the main mechanisms of the rational actor model are controlled for. In this specific context, being a churchgoing Catholic has a positive impact on the number of children ever born. In a second subsection, I show that a part of the influence of religiosity comes from the adherence to family-oriented values, and from the impact of the fertility of the respondent's parents. Even if they seem to be weak candidates to understand why religiosity has an impact on fertility, they are significant.

\subsection{Impact of religion and of economic characteristics}

In order to clearly determine the impact of religion and cultural transmission, I implement a step-by-step ZIP regression model (see Table 2). In a first regression (Model 1), neither religious nor cultural variables are considered. In a second regression (Model 2 ), the variables describing the cultural transmission from parents to children are introduced. These variables describe the respondent's parental fertility and the transmission

\footnotetext{
${ }^{24}$ See Baudin (2012) for a mathematical description.

25 To check the robustness for assumptions on the distribution, Baudin (2012) runs an ordered probit regression as in Fernández and Fogli (2007), as well as an ordinary least square regression.
} 
Baudin: Religion and fertility: The French connection

of family-oriented values within the family. In Model 3, I introduce the "Religious Family of Origin" variable describing whether the respondent has been raised in a Catholic family. In Model 4, the "Believer" variable is added. It is equal to one if the individual answers "Yes" to the question: "Are you a Believer?" In model 5, I add "Attendance to Religious Services" which measures the respondent's religiousness.

\section{Table 2: $\quad$ Zero-inflated poisson regression model}

\begin{tabular}{|c|c|c|c|c|c|c|}
\hline Poisson Part & Model 1 & Model 2 & Model 3 & Model 4 & Model 5 & Model 6 \\
\hline Female Income & $\begin{array}{l}-0.056 \\
(4.28) * * *\end{array}$ & $\begin{array}{l}-0.052 \\
(3.90) * * *\end{array}$ & $\begin{array}{l}-0.052 \\
(3.92) * * *\end{array}$ & $\begin{array}{l}-0.050 \\
(3.81) * * *\end{array}$ & $\begin{array}{l}-0.051 \\
(3.83) * * *\end{array}$ & $\begin{array}{l}-0.051 \\
(3.85) * * *\end{array}$ \\
\hline Male Income & $\begin{array}{l}0.030 \\
(3.61) * * *\end{array}$ & $\begin{array}{l}0.028 \\
(3.35) * * *\end{array}$ & $\begin{array}{l}0.028 \\
(3.39) * * *\end{array}$ & $\begin{array}{l}0.028 \\
(3.39) * * *\end{array}$ & $\begin{array}{l}0.029 \\
(3.46) * * *\end{array}$ & $\begin{array}{l}0.028 \\
(3.39) * * *\end{array}$ \\
\hline Small Town & $\begin{array}{l}0.127 \\
(3.14) * * *\end{array}$ & $\begin{array}{l}0.128 \\
(3.14) * * *\end{array}$ & $\begin{array}{l}0.129 \\
(3.17) * * *\end{array}$ & $\begin{array}{l}0.129 \\
(3.17) * * *\end{array}$ & $\begin{array}{l}0.125 \\
(3.08) * * *\end{array}$ & $\begin{array}{l}0.123 \\
(3.03) * * *\end{array}$ \\
\hline Live In Paris & $\begin{array}{l}-0.263 \\
(4.34) * * *\end{array}$ & $\begin{array}{l}-0.242 \\
(3.96) * * *\end{array}$ & $\begin{array}{l}-0.245 \\
(4.00) * * *\end{array}$ & $\begin{array}{l}-0.246 \\
(4.03) * * *\end{array}$ & $\begin{array}{l}-0.246 \\
(4.03) * * *\end{array}$ & $\begin{array}{l}-0.241 \\
(3.95) * * *\end{array}$ \\
\hline Primary Education & $\begin{array}{l}0.214 \\
(3.50) * * *\end{array}$ & $\begin{array}{l}0.201 \\
(3.28) * * *\end{array}$ & $\begin{array}{l}0.203 \\
(3.32) * * *\end{array}$ & $\begin{array}{l}0.200 \\
(3.25) * * *\end{array}$ & $\begin{array}{l}0.202 \\
(3.29) * * *\end{array}$ & $\begin{array}{l}0.200 \\
(3.27) * * *\end{array}$ \\
\hline Higher Education & $\begin{array}{c}-0.073 \\
(1.55)\end{array}$ & $\begin{array}{c}-0.06 \\
(1.27)\end{array}$ & $\begin{array}{c}-0.061 \\
(1.28)\end{array}$ & $\begin{array}{c}-0.062 \\
(1.30)\end{array}$ & $\begin{array}{c}-0.068 \\
(1.43)\end{array}$ & $\begin{array}{r}-0.067 \\
(1.41)\end{array}$ \\
\hline Never Married & $\begin{array}{l}-1.246 \\
(13.03) * * *\end{array}$ & $\begin{array}{l}-1.242 \\
(13.00) * * *\end{array}$ & $\begin{array}{l}-1.243 \\
(13.00) * * *\end{array}$ & $\begin{array}{l}-1.234 \\
(12.90) * * *\end{array}$ & $\begin{array}{l}-1.237 \\
(12.92) * * *\end{array}$ & $\begin{array}{l}-1.239 \\
(12.96) * * *\end{array}$ \\
\hline Over 45 & $\begin{array}{l}0.145 \\
(3.40) * * *\end{array}$ & $\begin{array}{l}0.138 \\
(3.24) * * *\end{array}$ & $\begin{array}{l}0.144 \\
(3.32) * * *\end{array}$ & $\begin{array}{l}0.138 \\
(3.19) * * *\end{array}$ & $\begin{array}{l}0.132 \\
(3.05) * * *\end{array}$ & $\begin{array}{l}0.125 \\
(2.91) * * *\end{array}$ \\
\hline Under 28 & $\begin{array}{l}-0.724 \\
(3.58) * * *\end{array}$ & $\begin{array}{l}-0.731 \\
(3.50) * * *\end{array}$ & $\begin{array}{l}-0.740 \\
(3.49) * * *\end{array}$ & $\begin{array}{l}-0.754 \\
(3.43) * * *\end{array}$ & $\begin{array}{l}-0.756 \\
(3.37) * * *\end{array}$ & $\begin{array}{l}-0.736 \\
(3.42) * * *\end{array}$ \\
\hline Parental Fertility & & $\begin{array}{c}0.034 \\
(2.36) * *\end{array}$ & $\begin{array}{c}0.034 \\
(2.37) * *\end{array}$ & $\begin{array}{c}0.034 \\
(2.37) * *\end{array}$ & $\begin{array}{c}0.034 \\
(2.35) * *\end{array}$ & $\begin{array}{l}0.033 \\
(2.33) * *\end{array}$ \\
\hline Family Values & & $\begin{array}{l}0.079 \\
(3.18) * * *\end{array}$ & $\begin{array}{l}0.080 \\
(3.22) * * *\end{array}$ & $\begin{array}{l}0.077 \\
(3.09) * * *\end{array}$ & $\begin{array}{l}0.075 \\
(3.04) * * *\end{array}$ & $\begin{array}{l}0.075 \\
(3.02) * * *\end{array}$ \\
\hline Religious Family of Origin & & & $\begin{array}{r}-0.047 \\
(0.79)\end{array}$ & $\begin{array}{c}-0.079 \\
(1.27)\end{array}$ & $\begin{array}{c}-0.090 \\
(1.43)\end{array}$ & \\
\hline Believer & & & & $\begin{array}{c}0.070 \\
(1.72) *\end{array}$ & $\begin{array}{c}0.025 \\
(0.53)\end{array}$ & \\
\hline $\begin{array}{l}\text { Attendance at Religious } \\
\text { Services }\end{array}$ & & & & & $\begin{array}{l}0.032 \\
(1.98) * *\end{array}$ & $\begin{array}{l}0.032 \\
(2.72) * * *\end{array}$ \\
\hline Constant & $\begin{array}{l}0.501 \\
(6.91) * * *\end{array}$ & $\begin{array}{l}0.312 \\
(3.26) * * *\end{array}$ & $\begin{array}{l}0.299 \\
(3.08) * * *\end{array}$ & $\begin{array}{l}0.256 \\
(2.56) * *\end{array}$ & $\begin{array}{l}0.197 \\
(1.88) *\end{array}$ & $\begin{array}{l}0.234 \\
(2.30) * *\end{array}$ \\
\hline \multicolumn{7}{|l|}{ Logit } \\
\hline Age & $\begin{array}{l}-0.593 \\
(5.43) * * *\end{array}$ & $\begin{array}{l}-0.630 \\
(5.38) * * *\end{array}$ & $\begin{array}{l}-0.642 \\
(5.36) * * *\end{array}$ & $\begin{array}{l}-0.664 \\
(5.35) * * *\end{array}$ & $\begin{array}{l}-0.680 \\
(5.33) * * *\end{array}$ & $\begin{array}{l}-0.648 \\
(5.37) * * *\end{array}$ \\
\hline Higher Education & $\begin{array}{l}1.509 \\
(2.09) * *\end{array}$ & $\begin{array}{l}1.543 \\
(2.09) * *\end{array}$ & $\begin{array}{l}1.546 \\
(2.09) * *\end{array}$ & $\begin{array}{l}1.538 \\
(2.07) * *\end{array}$ & $\begin{array}{l}1.571 \\
(2.09) * *\end{array}$ & $\begin{array}{l}1.567 \\
(2.11) * *\end{array}$ \\
\hline Small Town & $\begin{array}{l}-1.349 \\
(2.24) * *\end{array}$ & $\begin{array}{l}-1.383 \\
(2.27) * *\end{array}$ & $\begin{array}{l}1.383 \\
(2.26) * *\end{array}$ & $\begin{array}{l}-1.39 \\
(2.27) * *\end{array}$ & $\begin{array}{l}-1.38 \\
(2.09) * *\end{array}$ & $\begin{array}{l}-1.38 \\
(2.26) * *\end{array}$ \\
\hline Constant & $\begin{array}{l}13.684 \\
(3.34) * * *\end{array}$ & $\begin{array}{l}14.454 \\
(2.83) * * *\end{array}$ & $\begin{array}{l}14.695 \\
(2.66) * * *\end{array}$ & $\begin{array}{l}15.145 \\
(2.34) * *\end{array}$ & $\begin{array}{l}15.494 \\
(2.21) * *\end{array}$ & $\begin{array}{l}14.820 \\
(2.59) * * *\end{array}$ \\
\hline Pseudo $\mathrm{R}^{2}$ & 0,134 & 0,137 & 0,137 & 0,137 & 0,138 & 0,138 \\
\hline BIC & -8362 & -8363 & -8359 & -8354 & $4-83514$ & -8366 \\
\hline Vuong Statistic & $(3.82) * * *$ & $(3.80) * * *$ & $(3.80) * * *$ & $(3.76) * * *$ & $(3.74) * * *$ & $(3.76) * * *$ \\
\hline
\end{tabular}

Notes: * significant at $10 \% ;{ }^{* \star}$ significant at $5 \% ;{ }^{* \star *}$ significant at $1 \%$. Absolute value of $z$ stat in parentheses. 
In the present sample, the high number of zero counts is explained by the respondent's age, the size of her town and her higher education status. The older a woman is, the lower her probability of being childless. Furthermore, a woman who has engaged in higher education and does not live in a small town has a higher probability of choosing not to have children. ${ }^{26}$ The excess of zeroes is then explained by both the strong postponement of the first birth in developed economies (women tend to have their children after 28) and the fact that urban, highly educated women more often choose not to have children than other women.

Alternative regressions for the excess of zeroes have been tested (see Table A-1 in the appendix). I find that never having been married has no impact on deciding to be childless. It confirms that limiting the study to married woman may introduce a selection bias. Religiousness and primary education have no significant impact on the probability of being childless.

As shown in Model 2, having been raised in a larger family significantly increases the respondent's fertility. ${ }^{27}$ Furthermore, the transmission of family-oriented values between generations also increases fertility.

Another major result lies in the fact that having been raised in a Catholic family and proclaiming to be a religious believer do not significantly increase the number of children ever born (see Table 2). Indeed, in Model 4, the Believer variable is, a priori, significant because, used alone, it brings out two dimensions of the religious background: believing and practicing (religiousness). This is confirmed when religiosity is added to the regressions (see Model 5). In the end, religiousness, as measured by the frequency of attendance at religious services, is the only religious variable which significantly influences fertility.

The introduction of religious variables does not weaken the impact of the proxies for the transmission of fertility patterns and family-oriented values within the family while, as shown in the next subsection, the opposite is not true.

The Bayesian Information Criterion (BIC) indicates that Model 6 is very strongly preferred to Model 5. It confirms that both having been raised in a specific religion and being a believer are meaningless to explain fertility behaviors. Following Raftery (1996), the BIC indicates positive evidence in favor of Model 6 over Model 1, but this evidence is not strong. As Model 1 and 6 are nested, a Likelihood Ratio (LR) test can be run. It appears that Model 6 should be strongly preferred to Model $1 .^{28}$

The usual predictions of the rational actor model are also validated. Men's income and women's income have opposite effects. Female income has a negative impact on

${ }^{26}$ Baudin, de la Croix, and Gobbi (2015) propose a theoretical model of childlessness compatible with this finding.

27 Significance is understood as a successful $z$-test.

28 The null hypothesis is that the Attendance at Religious Services, Parental Fertility and Family Values coefficients are all equal to zero. The probability of preferring Model 6 over Model 1 while Model 1 fits the distribution better than Model 6 is equal to 0.0002 . 
women's fertility, while male income has a positive impact on it. This tends to confirm that the opportunity costs of fertility are essentially determined by female income. This interpretation is conditional on the assumption that mothers have to invest a greater share of their time in child rearing than do fathers. In line with the results of Ahn and Mira (2002), this effect is expected to be smaller in France than in some other European countries such as Germany, Greece and Italy. Indeed, public infrastructures and fiscal schemes in France allow women to reconcile a high participation rate in the labor market and high fertility.

School attainment has a significant impact on the number of CEB only for less educated women. Indeed, the number of CEB for a woman who has only completed primary education is $19.1 \%$ higher than that for a woman who has completed high school. Women with a university level education have a stronger probability of being childless, but when they decide to have children, their fertility is not significantly different from women who only have a high school diploma.

Finally, women who are under 28 years old exhibit a lower fertility than others. Indeed, in 2006, the average age of entry into fertility for French woman was 28. Furthermore, women over 45 are expected to have completed their reproduction process. As a consequence, they mechanically tend to have more children than women who have not yet completed their reproductive process. Notice that, as mentioned in the previous section, these effects are also suspected to derive from cohort effects. More specifically, the generous family policies implemented in France since 1994 have somewhat increased fertility. This could have altered the impact of the "Over 45 years old" variable, because the group of women over 45 completed their reproductive process without benefitting from generous subsidies for fertility. However, the effects of the position in the reproductive process are in line with the intuition, which indicates that the cohort effects are not too strong.

\subsection{The particularized ideology and socialization hypotheses}

As mentioned in the introduction, the impact of religion and religiosity on fertility can be due to the adherence to specific values, or to socialization. I propose here to run three regressions to detect these two channels (Table 3). ${ }^{29}$ As shown in Model A 3, I include religiosity, but I do not include the fertility of the respondent's parents or the adherence to family-oriented values. This model indicates that a one-standard-deviation increase in the Attendance at Religious Services increases the respondent's estimated fertility by a factor of 1.044. In other words, the estimated fertility of a woman with the highest religiousness is $24 \%$ higher than the estimated fertility of a woman without any religiousness.

\footnotetext{
${ }^{29}$ In these regressions, I exclude the higher education variable from the Poisson part of the regression as it was not significant in the main regressions. Obviously, excluding an even non-significant variable makes the other coefficients change at the very margin.
} 
Table 3: $\quad$ Tests for alternative hypotheses

\begin{tabular}{lrrr}
\hline & Model A & Model B & Model C \\
\hline Female Income & $-0.052 * * *$ & $-0.050 * * *$ & $-0.050 * * *$ \\
Male Income & $0.029 * * *$ & $0.028 * * *$ & $0.0273 * * *$ \\
Small Town & $0.115 * * *$ & $0.111 * * *$ & $0.119 * * *$ \\
Live In Paris & $-0.245 * * *$ & $-0.231 * * *$ & $-0.238 * * *$ \\
Primary Education & $0.193 * * *$ & $0.186 * * *$ & $0.190 * * *$ \\
Never Married & $-1.249 * * *$ & $-1.250 * * *$ & $-1.244 * * *$ \\
Over 45 & $0.121 * * *$ & $0.122 * * *$ & $0.114 * * *$ \\
Under 28 & $-0.482 * * *$ & $-0.486 * * *$ & $-0.476 * * *$ \\
Attendance at Religious Services & $0.0345 * * *$ & $0.0339 * * *$ & $0.0316 * *$ \\
Parental Fertility & & $0.0308 * *$ & \\
Family Values & & & $0.079 * * *$ \\
Constant & $0.419 * * *$ & $0.289 * * *$ & $0.381 * * *$ \\
\hline
\end{tabular}

Notes: * significant at $10 \%$; ${ }^{* *}$ significant at $5 \%$; ${ }^{* *}$ significant at $1 \%$. Absolute value of $z$ stat in parentheses, results of the Logistic part ignored.

In Model B, I add the fertility of the respondent's parents. I then obtain a parameter equal to 0.0334 , meaning that the fertility differential becomes $21.8 \%$. This result means that a part of the fertility differential between highly religious people and non-religious people comes from the fact that highly religious people have been raised in large families and reproduce this pattern in part in their own life.

In Model C, I replace the fertility of the respondent's parents by the Family Values variable. I obtain a parameter equal to 0.0316 and a fertility differential of $20.5 \%$ between highly religious people and non-religious people. It appears that compared to the first regression, the impact of religiosity is significantly smaller; furthermore the Attendance at Religious Services variable even looses some of its significance. This means that the particularized ideology hypothesis is a likelier explanation, as including the transmission of family values from parents to children explains in part why religiosity has a positive and significant impact on the number of children ever born. It seems that Family Values is a better detector of the particularized ideology hypothesis than the fertility of the respondent's parents; nevertheless these two detectors are significant.

Obviously, this way of controlling for the particularized ideology hypothesis remains weak, but to the best of my knowledge, it is the only way to show that this mechanism is at play in my data set. One should bear in mind that socialization has not been explicitly detected, and could also play a role. 
Baudin: Religion and fertility: The French connection

\section{Robustness checks}

The following subsections test the robustness of my results with respect to the way I measure religiousness and to sample selection.

\subsection{An alternative measure of religiousness}

The data set provides an alternative measure for religiousness. It consists in the answer to the question "Between 0 and 10, how do you rate the importance of religion in your own life?" This variable is subject to some caveats. First, religion can be important in a believer's life because he or she is very religious but, alternatively, religion can be important in a non-believer's life if his/her family or neighborhood are composed of churchgoers. In other words, the importance of religion in a person's life can reflect something else than his/her religiousness.

Furthermore, this measure consists in a subjective appreciation, while the frequency of church attendance is an objective criterion. Two respondents may have the same religious behavior, but they may give a difference subjective assessment of the importance of religion. "Marking" makes interpretations harder because differences in evaluation are less objective than differences in church attendance. To weaken this limitation, an "Estimated Religiousness" variable is constructed. It equals: $(i) 1$ if the respondent's answer belongs to [0,3], (ii) 2 if her answer belongs to [4,6] and (iii) 3 if it belongs to [7,10].

The "Attendance at Religious Services" variable has been replaced by the "Estimated Religiousness" variable in the zero-inflated Poisson regression model and also in an ordered probit regression model (see Table A-2 in the appendix). In the zero-inflated Poisson regression model, "Estimated Religiousness" has a significant positive impact on fertility when the "Catholic" and "Believer" variables are not taken into account. An LR test between the model with "Estimated Religiousness" and without it indicates that the first model is preferred at the 5 percent level. The differences in BIC are not conclusive. The estimated differential fertility between an agent who strongly cares about religion (Estimated Religiousness $=3$ ) and an agent who does not care about religion (Estimated Religiousness $=1$ ) is equal to $10.2 \%$. The same kind of result is found with the ordered probit regressions where BIC differences indicate a strong preference for the model which includes religiousness. Notice that, once again, the impact of the transmission of values in the family is robust to the introduction of religious variables.

Studying the impact of religion with the "Estimated Religiousness" variable is less conclusive than with church attendance. This is probably due to the inherent imperfections of this measure. However, whatever the chosen measure and the estimation strategy, having a strong religiousness always increases fertility, at least at the 5 percent confidence level. 
Interestingly enough, this result is the opposite of those of Frejka and Westoff (2008). In a multivariate analysis, they find, for Europe as a whole, that religiousness measured by church attendance has no significant impact on fertility, while the importance of religion in daily life is significant. One possible reason for such a different result may be that, when analyzing the impact of religiosity on fertility, France is closer to Southern European countries than to the rest of European countries. Indeed, for Southern European countries, Frejka and Westoff (2008) finds that church attendance remains a significant determinant of fertility. It is also important to notice that the regression model used in their article is different from a ZIP model.

\subsection{Alternative samples}

\subsubsection{Completed fertility}

As mentioned in Section 4, not all the women in the sample had completed their reproductive process at the time of the study. That is why I study the number of children ever born instead of completed fertility. Model 4 in Table 1 has been run on the sub-sample of women who completed their reproductive process. ${ }^{30}$ Intuitively, the distribution is less suspected to exhibit an excess of zero observations, since this phenomenon was mainly explained by the respondents' age. Indeed, a Vuong test indicates that the Poisson regression model is preferred to the ZIP regression model. ${ }^{31}$ An ordered probit regression model is also provided (see Table 6 in the appendix).

In both models, strong religiousness, measured by church attendance, increases the respondent's completed fertility. For example, as in the previous section, the fertility differential between strong churchgoers (Attendance at Religious Services $=6$ ) and agents who do not go to church at all, is about $16 \%$. Even if this fertility differential is smaller than for the number of children ever born, it is still strictly positive and highly significant even when I take into account the effect of the fertility of the parents (of the respondent), as well as the transmission of family values across generations.

\subsubsection{Entire sample}

Finally, as in Brañas-Garza and Neuman (2007), the zero-inflated Poisson regression model is also provided for the entire sample including men and women (Table 6). A "Female" dummy is introduced, it has a positive and significant impact on fertility. For

\footnotetext{
${ }^{30}$ It reduces the size of the sample to only 943 observations. The restriction of the sample to women who have completed their fertility has been used, among others, by Melkersson and Rooth (2000) and Santos Silva and Covas (2000).

${ }^{31}$ The Vuong statistic equals 0.83 . See Vuong (1989) for details.
} 
the whole population, the "Attendance at Religious Services" variable is strongly significant but exhibits a smaller value than for the women's sub-sample: the highest differential fertility between strong religiousness and no religiousness equals $18.2 \%$.

Obviously, measuring men's fertility is subject to errors, but once again, I can assert that my main results are not due to a bias from sample selection.

\section{Conclusion}

In this paper, I measure the impact of being a Catholic on fertility in France. I show that religiosity is the only religious variable which has an impact on the number of children a woman has. Thanks to a multivariate analysis, I also detect that a part of the influence of religiosity on fertility comes from the particularized ideology of Catholics. I also validate some conclusions of the rational actor model, such as the opposite effect of male and female income. These results are in line with a well-developed literature and are important, for instance, for policy makers. Indeed, family policies in France should not ignore the fact that there is a fertility differential between substantial parts of the population. Furthermore, the way child-allowances are distributed matters, as male and female income do not have the same effect on fertility.

Interestingly enough, my regressions show that religiosity has no impact on childlessness which clearly indicates that choosing to become a parent has to be differentiated from choosing the number of children one has.

\section{Acknowledgments}

I am grateful to Projet PRINCES 227301 1B1SHS ANR-05-BLAN-0270 which provided the data used in this paper. Projet Prince is not responsible for the mistakes and the interpretations which can be found in this paper. This research is part of the ARC project 09/14-018 on "sustainability" (French-speaking community of Belgium). I would like to thank two anonymous referees, as well as one associate editor for their comments which have led to a substantial revision of the paper. I also want to thank Luc Arrondel, Jean-Marc Tallon, Frédéric Jouneau, Victor Hiller, David de la Croix and Marie-Pierre Dargnies. The traditional disclaimer applies. 


\section{References}

Adserá, A. (2006). Marital Fertility and Religion: Recent Changes in Spain, 1985 and 1989. Population Studies 60(2): 205-221. doi:10.1080/00324720600684817.

Agadjanian, V. (2001). Religion, social milieu, and the contraceptive revolution. Population Studies 55(2): 135-148.

Ahn, N. and Mira, P. (2002). A Note on the Changing Relationship between Fertility and Female Employment Rates in Developed Countries. Journal of Population Economics 15(4): 667-682. doi:10.1007/s001480100078.

Alesina, A. and Giuliano, P. (2007). The Power of the Family. Cambridge, MA: National Bureau of Economic Research (NBER Working Paper No. 13051).

Amin, S., Diamond, I., and Steele, F. (1997). Contraception and Religiosity in Bangladesh. In: Jones, G.W., Douglas, R.M., Caldwell, J.C., and D’Souza, R.M. (eds.). The Continuing Demographic Transition. Oxford: Clarendon Press: 268-289.

Baudin, T. (2010). A Role For Cultural Transmission In Fertility Transitions. Macroeconomic Dynamics 14(4): 454-481. doi:10.1017/S1365100509090403.

Baudin, T. (2012). More on Religion and Fertility: The French Connection. mimeo, forthcoming as EQUIPPE Discussion Paper.

Baudin, T., de la Croix, D., and Gobbi, P. (2015). Fertility and Childlessness in the United States. American Economic Review. (Forthcoming).

Becker, G.S. (1960). An Economic Analysis of Fertility. In: Universities-National Bureau Committee for Economic Research (ed.). Demographic and Economic Change in Developed Countries. Princeton, NJ: Princeton University Press: 209-240.

Becker, G.S. and Lewis, H.G. (1973). On the Interaction Between the Quantity and Quality of Children. The Journal of Political Economy 81(2): S279-S288. doi:10.1086/ 260166.

Becker, G.S. and Stigler, J. (1977). De gustibus non est disputandum. American Economic Review 67(2): 76-90.

Becker, G.S. and Tomes, N. (1976). Child Endowments and the Quantity and Quality of Children. The Journal of Political Economy 84(4, Part 2: Essays in Labor Economics in Honor of H. Gregg Lewis): 143-162. doi:10.3386/w0123.

Berghammer, C. (2012). Church attendance and childbearing: Evidence from a Dutch panel study, 1987-2005. Population Studies 66(2). doi:10.1080/00324728.2012. 655304. 
Bisin, A. and Verdier, T. (2001). The Economics of Cultural Transmission and the Dynamic of Preferences. Journal of Economic Theory 97: 298-319. doi:10.1006/jeth. 2000.2678 .

Brañas-Garza, P. and Neuman, S. (2007). Parental religiosity and daughters? fertility: the case of Catholics in southern Europe. Review of Economics of the Household 5(3): 305-327. doi:10.1007/s11150-007-9011-4.

Browning, M., Chiappori, P.-A., and Lechene, V. (2006). Collective and Unitary Models: A Clarification. Review of Economics of the Household 4(1): 5-14. doi:10.1007/ s11150-005-6694-2.

Easterlin, R.A., Pollak, R.A., and Wachter, M.C. (1980). Toward a more general economic model of fertility determination: Endogenous preferences and natural fertility. In: Easterlin, R.A. (ed.). Population and Economic Change in Developing Countries. Chicago, IL: University of Chicago Press: 81-150.

Fernández, R. and Fogli, A. (2007). Women, Work, and Culture. Journal of the European Economic Association 5(2-3): 305-332.

Frejka, T. and Westoff, C.F. (2008). Religion, Religiousness and Fertility in the US and in Europe. European Journal of Population 24(1): 5-31. doi:10.1007/s10680-0079121-y.

Goldscheider, C. (1971). Population, Modernization and Social Structure. Boston, MA: Little, Brown and Company.

Guiso, L., Sapienza, P., and Zingales, L. (2006). Does Culture Affect Economic Outcomes? Journal of Economic Perspectives 20(2): 23-48. doi:10.1257/jep.20.2.23.

Hacker, J.D. (1999). Child Naming, Religion and the Decline of Marital Fertility in nineteenth Century America. The History of the Family 4(3): 339-365. doi:10.1016/S1081602X(99)00019-6.

Heineck, G. (2006). The relationship between religion and fertility: Evidence from Austria. Granada: University of Granada, Department of Economic Theory and Economic History (Papers on Economics of Religion 06/01).

Hervieu-Leger, D. (2004). Catholicisme, la fin d'un monde. Paris: Bayard.

Hotz, V.J., Klerman, J.A., and Willis, R.J. (1993). The economics of fertility in developed countries. In: Rosenzweig, M.R. and Stark, O. (eds.). Handbook of Population and Family Economics. Amsterdam: Elsevier: 275-347.

Laroque, G. and Salanié, B. (2005). Does Fertility Respond to Financial Incentives? London: Centre for Economic Policy Research (CEPR Discussion Papers 5007). 
Lesthaeghe, R.J. (1977). The Decline of Belgian Fertility 1800-1970. Princeton, NJ: Princeton University Press.

Lesthaeghe, R.J. and Wilson, C. (1986). Modes of production, secularization and the pace of the fertility decline in Western Europe, 1870-1930. Princeton, NJ: Princeton University Press.

Long, J.S. and Freese, J. (2006). Regression Models for Categorical Dependent Variables Using Stata. College Station, TX: Stata Press.

Mayeur, J.M. (2005). La séparation des Eglises et de l'Etat. Paris: Les Editions de l'Atelier.

McCullough, M.E., Enders, C.K., Brion, S.L., and Jain, A.R. (2005). The Varieties of Religious Development in Adulthood: A Longitudinal Investigation of Religion and Rational Choice. Journal of Personality and Social Psychology 89(1): 78-89. doi:10.1037/0022-3514.89.1.78.

Melkersson, M. and Rooth, D.O. (2000). Modeling Female Fertility Using Inflated Count Data Models. Journal of Population Economics 13(2): 189-203. doi:10.1007/ s001480050133.

Miranda, A. (2008). Planned fertility and family background: a quantile regression for counts analysis. Journal of Population Economics 21(1): 67-81. doi:10.1007/s00148007-0154-7.

Mosher, W.D., Johnson, D.P., and Williams, L.B. (1992). Religion and fertility in the United States: New patterns. Demography 29(2): 199-214. doi:10.2307/2061727.

Pollak, R.A. and Watkins, S.C. (1993). Cultural and Economic Approaches to Fertility: Proper Marriage or Mesalliance? Population and Development Review 19(3): 467496. doi:10.2307/2938463.

Prioux, F. and Régnier-Loilier, A. (2008). La pratique religieuse influence-t-elle les comportements familiaux? Population et Sociétés 447.

Raftery, A.E. (1996). Hypothesis testing and model selection. In: Gilks, W.R., Spiegelhalter, D.J., and Richardson, S. (eds.). Markov Chain Monte Carlo in Practice. London: Chapman and Hall: 163-188.

Rowland, D.T. (2007). Historical trends in childlessness. Journal of Family Issues 28: 1311-1337. doi:10.1177/0192513X07303823.

Santos Silva, J.M.C. and Covas, F. (2000). A modified hurdle model for completed fertility. Journal of Population Economics 13(2): 173-188. doi:10.1007/s001480050132. 
Stolzenberg, R.M., Blair-Loy, M., and Waite, L.J. (1995). Religious participation in early adulthood: age and family life cycle effects on church membership. American Sociological Review 60: 84-103. doi:10.2307/2096347.

Toulemon, L., Pailhé, A., and Rossier, C. (2008). France: High and stable fertility. Demographic Research 19(16): 503-556. doi:10.4054/DemRes.2008.19.16.

Vuong, Q.H. (1989). Likelihood ratio tests for model selection and non-nested hypotheses. Econometrica 57: 307-333. doi:10.2307/1912557.

Watkins, S.C. (1987). The Fertility Transition: Europe and the Third World Compared. Sociological Forum 2(4): 645-673. doi:10.1007/BF01124379.

Williams, L.B. and Zimmer, B.G. (1990). The Changing Influence of Religion on US Fertility: Evidence from Rhode Island. Demography 27(3): 475-481. doi:10.2307/ 2061381.

Zhang, L. (2008). Religious affiliation, religiosity, and male and female fertility. Demographic Research 18(8): 233-262. doi:10.4054/DemRes.2008.18.8. 


\section{Appendix}

\section{Table A-1: $\quad$ Alternative assumptions for the zero inflation}

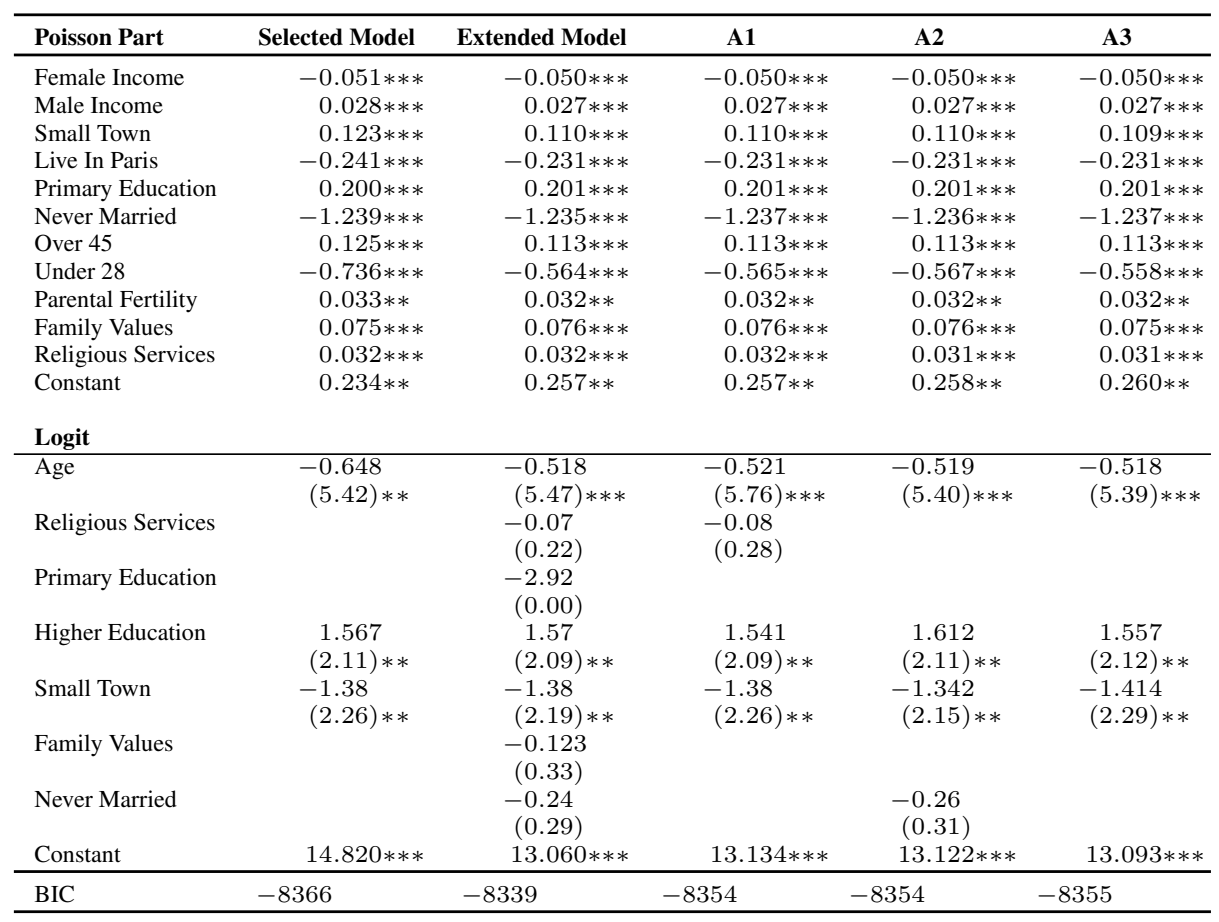

Notes: Observations 1,793, * significant at $10 \% ;{ }^{* *}$ significant at $5 \% ;{ }^{* \star *}$ significant at $1 \%$. Absolute value of $z$ statistics in parentheses, $\mathrm{z}$ values have been omitted for the Poisson part. 
Baudin: Religion and fertility: The French connection

Table A-2: $\quad$ Alternative measure of religiousness

\begin{tabular}{|c|c|c|c|c|c|c|}
\hline & ZIP 1 & ZIP 2 & ZIP 3 & Oprobit 1 & Oprobit 2 & Oprobit 3 \\
\hline Female Income & $\begin{array}{c}-0.050 \\
(3.79)^{\mathrm{a}}\end{array}$ & $\begin{array}{c}-0.050 \\
(3.79)^{\mathrm{a}}\end{array}$ & $\begin{array}{c}-0.055 \\
(4.17)^{\mathrm{a}}\end{array}$ & $\begin{array}{c}-0.080 \\
(4.35)^{\mathrm{a}}\end{array}$ & $\begin{array}{c}-0.080 \\
(4.34)^{\mathrm{a}}\end{array}$ & $\begin{array}{c}-0.087 \\
(4.79)^{\mathrm{a}}\end{array}$ \\
\hline Male Income & $\begin{array}{c}0.030 \\
(3.53)^{\mathrm{a}}\end{array}$ & $\begin{array}{c}0.029 \\
(3.45)^{\mathrm{a}}\end{array}$ & $\begin{array}{c}0.030 \\
(3.62)^{\mathrm{a}}\end{array}$ & $\begin{array}{c}0.052 \\
(4.43)^{\mathrm{a}}\end{array}$ & $\begin{array}{c}0.051 \\
(4.31)^{\mathrm{a}}\end{array}$ & $\begin{array}{c}0.052 \\
(4.51)^{\mathrm{a}}\end{array}$ \\
\hline Under 28 & $\begin{array}{c}-0.750 \\
(3.45)^{\mathrm{a}}\end{array}$ & $\begin{array}{c}-0.734 \\
(3.48)^{\mathrm{a}}\end{array}$ & $\begin{array}{c}-0.729 \\
(3.57)^{\mathrm{a}}\end{array}$ & $\begin{array}{l}-1.410 \\
(12.07)^{\mathrm{a}}\end{array}$ & $\begin{array}{c}-1.401 \\
(12.02)^{\mathrm{a}}\end{array}$ & $\begin{array}{l}-1.419 \\
(12.21)^{\mathrm{a}}\end{array}$ \\
\hline Over 45 & $\begin{array}{c}0.133 \\
(3.06)^{\mathrm{a}}\end{array}$ & $\begin{array}{c}0.126 \\
(2.91)^{\mathrm{a}}\end{array}$ & $\begin{array}{c}0.148 \\
(3.45)^{\mathrm{a}}\end{array}$ & $\begin{array}{c}0.207 \\
(3.48)^{\mathrm{a}}\end{array}$ & $\begin{array}{c}0.196 \\
(3.32)^{\mathrm{a}}\end{array}$ & $\begin{array}{c}0.230 \\
(3.95)^{\mathrm{a}}\end{array}$ \\
\hline Small Town & $\begin{array}{c}0.134 \\
(3.27)^{\mathrm{a}}\end{array}$ & $\begin{array}{c}0.132 \\
(3.23)^{\mathrm{a}}\end{array}$ & $\begin{array}{c}0.131 \\
(3.21)^{\mathrm{a}}\end{array}$ & $\begin{array}{c}0.258 \\
(4.47)^{\mathrm{a}}\end{array}$ & $\begin{array}{c}0.256 \\
(4.43)^{\mathrm{a}}\end{array}$ & $\begin{array}{c}0.253 \\
(4.38)^{\mathrm{a}}\end{array}$ \\
\hline Live In Paris & $\begin{array}{c}-0.244 \\
(3.98)^{\mathrm{a}}\end{array}$ & $\begin{array}{c}-0.239 \\
(3.91)^{\mathrm{a}}\end{array}$ & $\begin{array}{c}-0.260 \\
(4.27)^{\mathrm{a}}\end{array}$ & $\begin{array}{c}-0.349 \\
(4.56)^{\mathrm{a}}\end{array}$ & $\begin{array}{c}-0.342 \\
(4.47)^{\mathrm{a}}\end{array}$ & $\begin{array}{c}-0.371 \\
(4.88)^{\mathrm{a}}\end{array}$ \\
\hline Primary Education & $\begin{array}{c}0.174 \\
(2.78)^{\mathrm{a}}\end{array}$ & $\begin{array}{c}0.171 \\
(2.75)^{\mathrm{a}}\end{array}$ & $\begin{array}{c}0.192 \\
(3.09)^{\mathrm{a}}\end{array}$ & $\begin{array}{c}0.288 \\
(2.91)^{\mathrm{a}}\end{array}$ & $\begin{array}{c}0.285 \\
(2.87)^{\mathrm{a}}\end{array}$ & $\begin{array}{c}0.317 \\
(3.21)^{\mathrm{a}}\end{array}$ \\
\hline Never Married & $\begin{array}{l}-1.251 \\
(12.92)^{\mathrm{a}}\end{array}$ & $\begin{array}{l}-1.252 \\
(12.95)^{\mathrm{a}}\end{array}$ & $\begin{array}{l}-1.261 \\
(13.04)^{\mathrm{a}}\end{array}$ & $\begin{array}{l}-1.372 \\
(15.97)^{\mathrm{a}}\end{array}$ & $\begin{array}{c}-1.371 \\
(16.01)^{\mathrm{a}}\end{array}$ & $\begin{array}{l}-1.369 \\
(16.02)^{\mathrm{a}}\end{array}$ \\
\hline Parental Fertility & $\begin{array}{c}0.030 \\
(2.10)^{\mathrm{b}}\end{array}$ & $\begin{array}{c}0.030 \\
(2.08)^{\mathrm{b}}\end{array}$ & & $\begin{array}{c}0.057 \\
(2.83)^{\mathrm{a}}\end{array}$ & $\begin{array}{c}0.057 \\
(2.84)^{\mathrm{a}}\end{array}$ & \\
\hline Family Values & $\begin{array}{c}0.079 \\
(3.14)^{\mathrm{a}}\end{array}$ & $\begin{array}{c}0.078 \\
(3.11)^{\mathrm{a}}\end{array}$ & & $\begin{array}{c}0.146 \\
(4.15)^{\mathrm{a}}\end{array}$ & $\begin{array}{c}0.143 \\
(4.08)^{\mathrm{a}}\end{array}$ & \\
\hline Religious family of origin & $\begin{array}{r}-0.087 \\
(1.39)\end{array}$ & & & $\begin{array}{c}-0.143 \\
(1.75)^{\mathrm{c}}\end{array}$ & & \\
\hline Believer & $\begin{array}{c}0.010 \\
(0.20)\end{array}$ & & & $\begin{array}{c}0.007 \\
(0.10)\end{array}$ & & \\
\hline Estimated Religiousness & $\begin{array}{c}0.059 \\
(1.94)^{\mathrm{c}}\end{array}$ & $\begin{array}{c}0.056 \\
(2.29)^{\mathrm{b}}\end{array}$ & & $\begin{array}{c}0.094 \\
(2.18)^{\mathrm{b}}\end{array}$ & $\begin{array}{c}0.083 \\
(2.40)^{\mathrm{b}}\end{array}$ & \\
\hline Constant & $\begin{array}{c}0.193 \\
(1.81)^{\mathrm{c}}\end{array}$ & $\begin{array}{c}0.228 \\
(2.19)^{\mathrm{b}}\end{array}$ & $\begin{array}{c}0.494 \\
(6.78)^{\mathrm{a}}\end{array}$ & & & \\
\hline $\begin{array}{l}\text { Pseudo R } \\
\text { BIC }\end{array}$ & $\begin{array}{c}0.138 \\
-8257\end{array}$ & $\begin{array}{c}0.138 \\
-8270\end{array}$ & $\begin{array}{c}0.134 \\
-8268\end{array}$ & $\begin{array}{c}0.151 \\
-8379\end{array}$ & $\begin{array}{l}0.15 \\
-8391\end{array}$ & $\begin{array}{c}0.145 \\
-8381\end{array}$ \\
\hline
\end{tabular}

Notes: Observations 1,774, results for Logit deleted. Absolute value of $z$ statistics in parentheses; ${ }^{\mathrm{c}}$ significant at $10 \% ;{ }^{b}$ significant at $5 \%{ }^{\text {a }}$ significant at $1 \%$. 